\begin{abstract}
A recent study determined that when simultaneously exposed to 2 different commonly used baits, certain shark species demonstrate preferences for a specific bait on bottom longlines. To further investigate the value of bait type to reduce shark bycatch, we conducted single-bait-type bottom longline sets with standardized gear baited with either mackerel or squid. For 4 of the 5 shark species captured, there was no significant difference in catch rates with bait type. However, catch rates of Atlantic sharpnose sharks (Rhizoprionodon terraenovae) were significantly higher on mackerel-baited hooks. Our results indicate that the use of squid as bait can reduce the catch of at least one shark species in the northern Gulf of Mexico while not reducing the catch of a targeted species, in this case, the red snapper (Lutjanus campechanus). However, because some protected species, most notably sea turtles, have been shown to have higher catch rates on squid-baited hooks, it is necessary to assess the effect of a specific bait across all taxa directly or indirectly affected by a particular gear type before adopting any bycatch reduction measure.
\end{abstract}

Manuscript submitted 25 March 2019. Manuscript accepted 24 July 2019. Fish. Bull. 117:189-195 (2019).

Online publication date: 1 August 2019. doi: 10.7755/FB.117.3.6

The views and opinions expressed or implied in this article are those of the author (or authors) and do not necessarily reflect the position of the National Marine Fisheries Service, NOAA.

\title{
Efficacy of 2 common bait types in reducing bycatch of coastal sharks on bottom longline gear in the absence of choice
}

\author{
William B. Driggers III (contact author) ${ }^{1}$ \\ Kristin M. Hannan ${ }^{2}$ \\ Email address for contact author: william.driggers@noaa.gov \\ ${ }^{1}$ Mississippi Laboratories \\ Southeast Fisheries Science Center \\ National Marine Fisheries Service, NOAA \\ 3209 Frederic Street \\ Pascagoula, Mississippi 39567-4112 \\ ${ }^{2}$ Riverside Technology Inc. \\ Mississippi Laboratories \\ Southeast Fisheries Science Center \\ National Marine Fisheries Service, NOAA \\ 3209 Frederic Street \\ Pascagoula, Mississippi 39567-4112
}

Globally, shark populations are widely reported to be in decline (for a recent review, see Dulvy et al., 2014). Although a number of factors contribute to this trend, bycatch of sharks is a primary factor (Oliver et al., 2015). A number of potential shark bycatch mitigation measures have been considered, including time or area closures, gear modifications, adaptive fishing practices, and use of repellents (Molina and Cooke, 2012). Several studies have investigated the efficacy of bait type in reducing shark bycatch rates (e.g., Broadhurst and Hazin, 2001; Watson et al., 2005; Yokota et al., 2009); however, results of studies examining the relationship between catch rates and bait type on longline gear are often conflicting. For example, in studies with comparable gear comparing squid and mackerel baits, Watson et al. (2005) and Foster et al. (2012) found that catch of blue sharks (Prionace glauca) was highest on pelagic longlines when squid (Illex spp.) was used compared with when bait of Atlantic mackerel (Scomber scombrus) was used, whereas Coelho et al. (2012) reported a higher catch of blue sharks on mackerel (Scomber spp.) bait than on squid bait. All 3 studies used a single bait type on each longline set. However, none addressed potential biasing factors of this experimental design in assessing bait preference of blue sharks, most notably the propensity for this shark species to form large aggregations in discrete locations (e.g., Kenney et al., 1985; Litvinov, 2006) where only a single bait type would have been used.

Driggers et al. (2017) examined catch rates and bait preferences of fish species captured on bottom longline gear in the northern Gulf of Mexico using an experimental design alternating 2 bait types on individual bottom longline sets. The results of this study indicate that several shark species, including the little gulper shark (Centrophorus uyato), smooth dogfish (Mustelus canis), blacknose shark (Carcharhinus acronotus), sandbar shark (C. plumbeus), and Atlantic sharpnose shark (Rhizoprionodon terraenovae), showed a preference for Atlantic mackerel over northern shortfin 
squid (Illex illecebrosus). Conversely, teleosts commonly targeted with bottom longline gear in the northern Gulf of Mexico, such as red snapper (Lutjanus campechanus), yellowedge grouper (Hyporthodus flavolimbatus), and tilefish (Lopholatilus chamaeleonticeps), showed no preference. The authors acknowledged that the use of alternating bait types could have biased results because of potential interaction effects of baits, a possibility suggested by Watson et al. (2005) and Foster et al. (2012). To address this issue and further investigate the efficacy of bait type in reducing shark bycatch, the objective of this study was to assess if the preference of sharks for Atlantic mackerel over northern shortfin squid baits reported by Driggers et al. (2017) would be evident in a single-bait experimental design.

\section{Materials and methods}

Bottom longline gear was deployed from the NOAA Ship Oregon II in the northern Gulf of Mexico from 26 March through 19 April 2017. All sets were made within an area bounded by $87.50^{\circ} \mathrm{W}$ to $93.00^{\circ} \mathrm{W}$ longitude at depths between 15 and $85 \mathrm{~m}$ (Fig. 1). Stations were preselected on the basis of a random starting point and subsequent stations being spaced $18.5 \mathrm{~km}$ apart in a grid to maximize sampling effort and minimize effects of sampling sites being in close proximity to one another. On several occasions, preselected stations were moved to avoid hazards to navigation (e.g., vessels, petroleum platforms, and shipping lanes) or excessively fast currents $(>1 \mathrm{~m} / \mathrm{s})$. Sampling gear consisted of $1.8 \mathrm{~km}$ of $4-\mathrm{mm}$ diameter monofilament mainline and 100 gangions. Each gangion was constructed of a size $148-8 / 0$ snap, $3.2 \mathrm{~m}$ of $3-\mathrm{mm}$ diameter monofilament, $0.5 \mathrm{~m}$ of $2.4-\mathrm{mm}$ diameter fishing wire, and a hook (\#15/0 non-offset, circle, Mustad \#39960D ${ }^{1}$, O. Mustad \& Søn A.S., Gjøvik, Norway) and was identical to that used in Driggers et al. (2017). Each hook was baited with Atlantic mackerel or northern shortfin squid cut to fit the circle hooks. Bait consisted either entirely of Atlantic mackerel or northern shortfin squid for each longline set with bait randomly assigned at the beginning of each set.

Bottom temperature (in degrees Celsius) and salinity were measured at each sampling location, while the longline gear was in the water, by using an SBE 911plus CTD water profiler (Sea-Bird Scientific, Bellevue, WA). Soak time, defined as the time elapsed from completing deployment of the gear to beginning retrieval of the gear, was limited to $1 \mathrm{~h}$ in an effort to minimize mortality rates of

\footnotetext{
${ }^{1}$ Mention of trade names or commercial companies is for identification purposes only and does not imply endorsement by the National Marine Fisheries Service, NOAA.
}

captured organisms and to maximize the number of longline sets conducted during the allotted sampling period. Further, the relatively short soak time reduced data loss associated with shark depredation and potential bias associated with capturing large sharks feeding upon smaller captured fish, a behavior that would not reflect preference for Atlantic mackerel or northern shortfin squid. Upon capture, each fish was identified to species and its fork length was measured to the nearest millimeter on a straight line along the axis of the body from the tip of the rostrum to the caudal notch.

Depth, temperature, salinity, soak-time, and fish-length data associated with sampling locations where each bait was used were assessed for normality and homoscedasticity by calculating kurtosis, skewness, and $F$-ratio. Data were considered normally distributed when kurtosis and skewness were between -2 and 2 . For data that adhered to the assumptions of parametric statistics, $t$-tests were used to compare mean values; for data that did not meet assumptions, median values were compared by using a Mann-Whitney W test. To determine if the number of individuals captured on each bait was significantly different from 1:1, a chi-square test with Yates correction for continuity was used on a species-specific basis. Sharks that were captured on hooks occupied by a smaller captured fish were removed from all analyses ( 2 blacktip sharks, Carcharhinus limbatus), and fish not measured because of shark-inflicted damage were excluded from comparisons of body length.

To account for the possibility that catch data were biased because of schooling behavior or areas of high abundance (i.e., high catch in limited cases because of habitat specificity or aggregations), catch data for each species were examined to determine if an unusually high number of individuals were caught on any specific set. 
The mean number of a given species captured on all sets, regardless of bait, was calculated. All sets where the total number of individuals captured was greater than 3 standard deviations from the mean were considered outliers and removed from analyses. For those species for which outliers were identified, chi-square tests based on revised expected values were conducted. Revised expected values were calculated by subtracting sets with identified outliers from the total number of sets conducted with the corresponding bait and then dividing the remaining number of sets with Atlantic mackerel bait by the number of sets with northern shortfin squid bait. All statistical tests were considered significant at an $\alpha$ level of 0.05 .

\section{Results}

Of the 104 longline sets conducted for this study, 52 sets used northern shortfin squid as bait and 52 sets used Atlantic mackerel as bait (Fig. 1). There was no significant difference in the mean depth $(t=-0.58, P=0.56)$ or temperature $(t=-0.30, P=0.77)$ between sets that used the 2 types of bait (Table 1). Similarly, there was no significant difference in the median bottom salinity ( $W=1426.0$, $P=0.40$ ) among sampling locations where the 2 baits were used (Table 1). Soak times ranged from 57 to $65 \mathrm{~min}$, and there was no significant difference between soak times on sets that used mackerel or squid for bait $(t=0.28, P=0.78)$ (Table 1). Among all sets, regardless of bait, 1572 fish from 25 species were captured; however, 6 of these species made up $91.3 \%$ of the total catch. Those species were the Gulf smoothhound (Mustelus sinusmexicanus), Atlantic sharpnose shark, blacknose shark, blacktip shark, scalloped hammerhead (Sphyrna lewini), and red snapper (Table 2). Species that constituted less than $1 \%$ of the total catch or were caught on fewer than 10 sets were not considered in subsequent analyses.
All captured fish had corresponding body length measurements with the exception of 23 specimens damaged by sharks (14 red snapper and 9 Atlantic sharpnose sharks). The mean or median fork length (FL) of all species examined did not differ by bait, with the exception of those for the Atlantic sharpnose shark, specimens of which were larger on sets with bait of Atlantic mackerel (median: $806 \mathrm{~mm} \mathrm{FL)} \mathrm{than} \mathrm{on} \mathrm{sets} \mathrm{with} \mathrm{bait} \mathrm{of} \mathrm{north-}$ ern shortfin squid (median: $781 \mathrm{~mm} \mathrm{FL)} \mathrm{(W=49994.4,}$ $P<0.01$ ) (Fig. 2, Table 2). However, there was a greater size range (323-970 mm FL) of Atlantic sharpnose sharks captured on sets baited with Atlantic mackerel compared with the size range on sets baited with northern shortfin squid (487-961 mm FL).

The total catch of all species on each bait was not different from the expected ratio of 1:1, with the exception of the catch of Atlantic sharpnose sharks, which were more frequently captured on sets baited with Atlantic mackerel $(n=488)$ than on northern shortfin squid-baited sets $(n=302)\left(\chi^{2}=43.32, P<0.01\right)$ (Table 2). Outliers indicating unusually large catches were detected for Atlantic sharpnose sharks, blacknose sharks, blacktip sharks, and scalloped hammerheads (Table 3). After removing outliers, Atlantic sharpnose sharks $\left(\chi^{2}=12.14, P<0.01\right)$ and blacknose sharks $\left(\chi^{2}=4.92, P=0.03\right)$ were caught more frequently on sets baited with Atlantic mackerel. However, there remained no significant relationship between bait type and catch rates of blacktip sharks $\left(\chi^{2}=0.02, P=0.87\right)$ or scalloped hammerheads $\left(\chi^{2}=0.01\right.$, $P=0.92$ ).

\section{Discussion}

Results of our study indicate that for Gulf smoothhounds, blacktip sharks, scalloped hammerheads, and red snapper, there was no difference in capture rates related to bait. However, preference for Atlantic mackerel bait over

\section{Table 1}

Comparison of abiotic variables and soak times associated with bottom longline sets conducted with baits of Atlantic mackerel (Scomber scombrus) or northern shortfin squid (Ilex illecebrosus) in the northern Gulf of Mexico during March-April 2017. Means are given with standard errors of the mean (SEs). Results from $t$-tests and Mann-Whitney (M-W) W tests are provided with their associated $P$-values in parentheses.

\begin{tabular}{lllllll}
\hline Variable & Bait type & Range & Mean (SE) & Median & $t$-value $(P)$ & M-W test $(P)$ \\
\hline Depth $(\mathrm{m})$ & Mackerel & $15.3-83.1$ & $40.51(2.22)$ & 39.0 & $-0.58(0.56)$ & $1425.5(0.64)$ \\
& Squid & $15.9-77.3$ & $42.41(2.34)$ & 37.3 & & \\
Temperature $\left({ }^{\circ} \mathrm{C}\right)$ & Mackerel & $19.8-23.0$ & $21.48(0.13)$ & 21.4 & $-0.30(0.77)$ & $1369.5(0.64)$ \\
& Squid & $19.5-23.1$ & $21.53(0.13)$ & 21.5 & - & $1426.0(0.40)$ \\
Salinity & Mackerel & $31.3-36.4$ & $35.74(0.14)$ & 36.2 & 36.2 & \\
\multirow{3}{*}{ Soak time (min) } & Squid & $32.5-36.5$ & $35.90(0.10)$ & 60.5 & $0.28(0.78)$ & $1308.0(0.77)$ \\
& Mackerel & $57.0-65.0$ & $60.61(0.25)$ & 61.0 & &
\end{tabular}


Table 2

Number of individuals $(n)$, size range (millimeters fork length [FL]), mean size (mm FL), median size (mm FL), and test statistics for species caught on longline sets baited with Atlantic mackerel (Scomber scombrus) or northern shortfin squid (Ilex illecebrosus) in the northern Gulf of Mexico during March-April 2017. Statistics from $t$-tests, Mann-Whitney W tests, and chi-square tests are presented with associated $P$-values in parentheses. An asterisk $(*)$ indicates data that did not meet the assumptions of normality or homoscedasticity.

\begin{tabular}{llrrrrrrr}
\hline Species & Bait type & $n$ & Size range & Mean (SE) & Median & $t$-value $(P)$ & W test $(P)$ & Chi-square test $(P)$ \\
\hline Gulf smoothhound & Mackerel & 51 & $573-1207$ & $902.4(19.8)$ & 900.0 & & \\
& Squid & 39 & $402-1143$ & $867.7(21.3)$ & 819.0 & $1.70(0.08)$ & $769.0(0.07)$ & $1.34(0.25)$ \\
Atlantic sharpnose & Mackerel & 488 & $323-970$ & $793.8(3.1)$ & 806.0 & $6.22(<0.01)^{*}$ & $49,994.4(<0.01)$ & $43.32(<0.01)$ \\
shark & Squid & 302 & $487-961$ & $759.5(5.0)$ & 781.0 & & & \\
Blacknose shark & Mackerel & 33 & $584-1057$ & $861.1(21.8)$ & 884.0 & $0.14(0.89)$ & $363.0(0.78)$ & $2.24(0.13)$ \\
& Squid & 21 & $589-1015$ & $855.6(33.8)$ & 922.0 & & \\
Blacktip shark & Mackerel & 18 & $990-1214$ & $1100.3(62.1)$ & 1115.0 & $-0.98(0.33)$ & $148.5(0.58)$ & $0.52(0.47)$ \\
& Squid & 13 & $1015-1250$ & $1125.9(23.7)$ & 1096.0 & & & \\
Scalloped & Mackerel & 46 & $643-1880$ & $1254.5(45.8)$ & 1237.0 & $0.17(0.86)$ & $1177.0(0.77)$ & $0.36(0.55)$ \\
hammerhead & Squid & 53 & $646-1820$ & $1243.5(43.5)$ & 1210.0 & & & \\
Red snapper & Mackerel & 198 & $530-880$ & $708.1(4.4)$ & 706.0 & $0.49(0.62 *$ & $17,554.0(0.33)$ & $0.02(0.88)$ \\
& Squid & 202 & $605-881$ & $705.3(3.4)$ & 699.5 & & & \\
\hline
\end{tabular}

northern shortfin squid bait was evident for Atlantic sharpnose sharks both when not accounting for and when accounting for sets with unusually high catches. This result, in agreement with the findings of Driggers et al. (2017), demonstrates that bait type is a viable option for shark bycatch reduction albeit on a species-specific basis. Further, the catch of red snapper was not affected by bait type in this study or in Driggers et al. (2017), indicating that shark catch can be reduced without affecting the catch of target species when bait type is used as a bycatch mitigation measure.

For blacknose sharks, there was no difference in catch rates between bait types unless unusually high catch rates identified as outliers were removed from the data set. Driggers et al. (2017) reported that, when both baits were alternated on a single set, the catch of blacknose sharks was over 5 times greater when Atlantic mackerel was used for bait compared with catch when northern shortfin squid was used. This finding is consistent with past reports that the diet of blacknose sharks is primarily piscivorous (e.g., Castro, 2011). For example, Dodrill (1977) reported that stomach contents of all blacknose sharks he examined contained teleost prey. Similarly, Cortés (1999) reported that the diet of blacknose sharks consisted of $98.2 \%$ teleosts, with less than $2 \%$ consisting of crustaceans and noncephalopod mollusks. Ford (2012), on the basis of a sample size larger than the combined sample size reported in the Dodrill (1977) and Cortés (1999) studies, found that fish compose $63.4 \%$ of the diet of blacknose sharks off the East Coast of the United States, with the remainder composed of invertebrates, including squid and octopods (11.4\%).

Results of our study and those of Ford (2012) indicate that blacknose sharks are more opportunistic than previously thought. Additionally, when considered in conjunction with the findings of Driggers et al. (2017), although the species shows a clear preference for teleosts, blacknose sharks will opportunistically prey on other organisms when their preferred prey is not present. Although there were fewer blacknose sharks captured on sets baited with northern shortfin squid during our study, the difference in capture rates between the 2 baits was not significantly different. Therefore, on the basis of the data from our study, bait choice does not appear to be an efficient bycatch mitigation measure for the blacknose shark. However, it is important to note that only 54 blacknose sharks were captured during this study, and if a real effect was present, it could have been obfuscated by the relatively low sample size.

Like blacknose sharks, blacktip sharks are reported to feed primarily on teleosts (e.g., Castro, 1996; Bethea et al., 2004; Barry et al., 2008). For example, Hoffmayer and Parsons (2003) examined the diet of blacktip sharks in the Mississippi Sound and determined that 95\% of the diet of this species was composed of teleosts. Results of this study demonstrate that blacktip sharks are opportunistic and, although they specialize in feeding on teleosts, they will feed on both squid and teleost baits, negating the value of bait type as a bycatch mitigation measure for this species. A similar conclusion was reached for the effect of bait type on catch rates of the Gulf smoothhound, scalloped hammerhead, and red snapper. This result was not unexpected because scalloped hammerheads and red snapper are known to have relatively wide dietary breadths, including teleosts and cephalopods (Stevens and Lyle, 1989; Szedlmayer and Lee, 2004; Wells et al., 2008; Vaske et al., 2009; Torres-Rojas et al., 2010). Further, to our knowledge, no species-specific diet studies have been conducted for the 


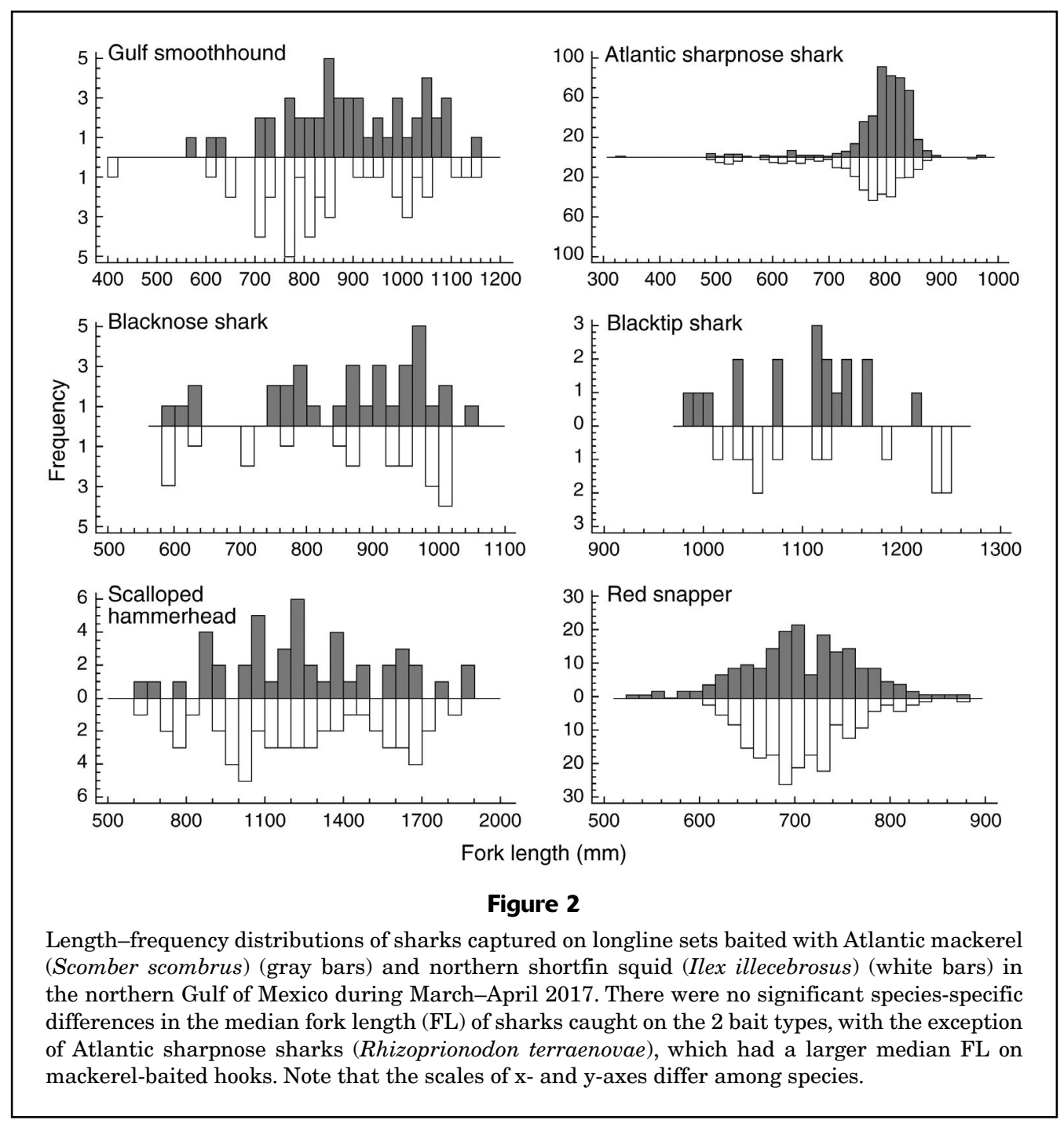

Gulf smoothhound; however, Cortés (1999) summarized the diet of 13 species within the morphologically conservative genus Mustelus and demonstrated that these fishes have a diverse diet. For example, dietary studies of the smooth dogfish, which is sympatric with and has the same dental morphology as the Gulf smoothhound, indicate that its diet consists of decapod crustaceans, teleosts, and non-decapod invertebrates in decreasing order (Cortés, 1999).

Pitcher et al. (1982) empirically tested the effect of shoal size on the amount of time it took goldfish (Carassius auratus) and minnows (Phoxinus phoxinus) to locate a food source, and they found that foraging efficiency increased with shoal size for both species. Among coastal shark species captured during 3500 fishery-independent bottom longline sets conducted throughout the northern Gulf of Mexico as part of a survey by the National Marine Fisheries Service, Southeast Fisheries Science Center, Mississippi Laboratories, the Atlantic sharpnose shark is not only the most commonly caught species $(n=15,494$ individuals) but also the species most commonly caught in schools of 10 individuals or larger (number of sets $=513$, school size range of 10-72 sharks). If there is a link between shoal size and preferred bait detection for Atlantic sharpnose sharks, as our results indicate, it is possible that other species have a preference for a specific bait when shoaling. Because individuals of some shark species, such as the blacktip shark, spinner shark (Carcharhinus brevipinna), and scalloped hammerhead, form large shoals within the Gulf of Mexico during certain times of the year (senior author, unpubl. data), it is possible that bait preference could be exhibited during those periods but absent at other times when individuals are more dispersed. Future research should examine this hypothesis and test how the use of bait type as a bycatch mitigation measure can vary seasonally.

The combined results of this study and Driggers et al. (2017) provide the first comparison, as far as we are aware of, between the effect of bait type on catch rates of sharks caught on standardized longline gear with single-bait-type 


\section{Table 3}

Range of number of individuals caught per set, mean number caught per set, and number of sets identified as outliers for species caught on longline sets baited with Atlantic mackerel (Scomber scombrus) or northern shortfin squid (Ilex illecebrosus) in the northern Gulf of Mexico during March-April 2017. Values provided in parentheses represent number of individuals caught in longline sets identified as outliers or $P$-values associated with $\chi^{2}$ values from chi-square tests. Note that no catches of Gulf smoothhounds (Mustelus sinusmexicanus) or red snapper (Lutjanus campechanus) were identified as outliers. Therefore, no associated expected ratios or $\chi^{2}$ values are presented for either species. $\mathrm{SD}=$ standard deviation.

\begin{tabular}{|c|c|c|c|c|c|c|}
\hline Species & Bait type & No. per set & Mean +3 SD & No. of outliers & Expected ratio & $\chi^{2}$ \\
\hline Gulf smoothhound & $\begin{array}{l}\text { Mackerel } \\
\text { Squid }\end{array}$ & $\begin{array}{l}1-8 \\
1-7\end{array}$ & 9.81 & $\begin{array}{l}0 \\
0\end{array}$ & - & - \\
\hline Atlantic sharpnose shark & $\begin{array}{l}\text { Mackerel } \\
\text { Squid }\end{array}$ & $\begin{array}{l}1-50 \\
1-31\end{array}$ & 42.22 & $\begin{array}{l}2(43,50) \\
0\end{array}$ & $0.96: 1$ & $12.14(<0.01)$ \\
\hline Blacknose shark & $\begin{array}{l}\text { Mackerel } \\
\text { Squid }\end{array}$ & $\begin{array}{l}1-4 \\
1-5\end{array}$ & 4.77 & $\begin{array}{l}0 \\
1(5)\end{array}$ & $1.02: 0$ & $4.92(0.03)$ \\
\hline Blacktip shark & $\begin{array}{l}\text { Mackerel } \\
\text { Squid }\end{array}$ & $\begin{array}{l}1-7 \\
1-3\end{array}$ & 5.90 & $\begin{array}{l}1(7) \\
0\end{array}$ & $0.98: 1$ & $0.02(0.87)$ \\
\hline Scalloped hammerhead & $\begin{array}{l}\text { Mackerel } \\
\text { Squid }\end{array}$ & $\begin{array}{l}1-5 \\
1-6\end{array}$ & 5.15 & $\begin{array}{l}0 \\
1(6)\end{array}$ & $1.02: 0$ & $0.01(0.92)$ \\
\hline Red snapper & $\begin{array}{l}\text { Mackerel } \\
\text { Squid }\end{array}$ & $\begin{array}{l}1-15 \\
1-18\end{array}$ & 22.50 & $\begin{array}{l}0 \\
0\end{array}$ & - & - \\
\hline
\end{tabular}

sets and alternating-bait-type sets. A valid criticism of Driggers et al. (2017) is related to possible interaction effects when bait type is alternated on a single set, as suggested by Watson et al. (2005) and Foster et al. (2012). Although this concern is reasonable, if an interaction effect occurred, a statistically equal number of individuals of a given species would be expected to be caught on each bait. The results of Driggers et al. (2017) indicate significant bait type preference for 5 shark species and a clear trend for 3 other species; therefore, we believe the concern is unwarranted. However, the results of our study, for which we used a single-bait approach, indicate that in the absence of choice, most, but not all, species that Driggers et al. (2017) found demonstrated a bait preference will ingest whichever bait is available. Therefore, we conclude that studies examining the effect of bait type on catch rates with longline gear should use both single-bait and alternating bait approaches to determine the degree of bait preference and if a specific bait affects catch rates in such a way that would warrant management measures. Further, bait comparison studies that employ a single-bait approach must demonstrate that all bait types were fished in comparable abiotic and biotic conditions.

Results of our study indicate that it is important that bait type be accounted for when analyzing fisherydependent and fishery-independent catch data rather than assuming there is no difference in catch rates among different baits. Although this assumption would have little to no effect when examining a species with no bait preference, in certain cases, such as when examining trends in abundance of Atlantic sharpnose sharks, significant bias would be introduced. Additionally, there can be a cascading effect whereby captured fish become bait themselves, therefore introducing unexpected biases for other species showing preferences. For example, during the Mississippi Laboratories survey, Atlantic mackerel has been the sole bait used since 1995. During this time, $26 \%$ of all bull sharks (C. leucas) have been caught on hooks occupied by captured Atlantic sharpnose sharks (senior author, unpubl. data). If a change were made from Atlantic mackerel bait to northern shortfin squid bait, on the basis of the results of this study, fewer Atlantic sharpnose sharks would be expected to be captured, and in turn fewer bull sharks, a species whose diet has been reported to consist to a large extent $(35.4 \%)$ of smaller sharks (Cortés, 1999), would be captured.

In addition to indicating the importance of considering bait type in analyses of catch data, the results of this study demonstrate that the use of squid as bait can reduce the catch of at least one shark species in the northern Gulf of Mexico and could be employed as a bycatch reduction measure. However, some protected species, such as the loggerhead (Caretta caretta) and leatherback (Dermochelys coriacea) sea turtles, have been shown to have higher bycatch rates on squid-baited hooks (e.g., Watson et al., 2005). Therefore, the effect of a specific bait across all taxa that are directly or indirectly affected by a particular gear type must be assessed before adopting any bycatch reduction measure.

\section{Acknowledgments}

We thank the crew of the NOAA Ship Oregon II, P. Felts, E. Hoffmayer, N. Hopkins, C. Jones, L. Jones, K. Rademacher, C. Stepongzi, and T. Wallace for their field assistance. 


\section{Literature cited}

Barry, K. P., R. E. Condrey, W. B. Driggers III, and C. M. Jones. 2008. Feeding ecology of neonate and juvenile blacktip sharks Carcharhinus limbatus in the Timbalier-Terrebone Bay complex, LA, U.S.A. J. Fish Biol. 73:650-662. Crossref

Bethea, D. M., J. A. Buckel, and J. K. Carlson.

2004. Foraging ecology of the early life stages of four sympatric shark species. Mar. Ecol. Prog. Ser. 268:245-264. Crossref

Broadhurst, M. K., and F. H. V. Hazin.

2001. Influences of type and orientation of bait on catches of swordfish (Xiphias gladius) and other species in an artisanal sub-surface longline fishery off northeastern Brazil. Fish. Res. 53:169-179. Crossref

Castro, J. I.

1996. Biology of the blacktip shark, Carcharhinus limbatus, off the southeastern United States. Bull. Mar. Sci. 59:508-522.

2011. The sharks of North America, 613 p. Oxford Univ. Press, New York.

Coelho, R., M. N. Santos, and S. Amorim.

2012. Effects of hook and bait on targeted and bycatch fishes in an equatorial Atlantic pelagic longline fishery. Bull. Mar. Sci. 88:449-467. Crossref

Cortés, E.

1999. Standardized diet compositions and trophic levels of sharks. ICES J. Mar. Sci. 56:707-717. Crossref

Dodrill, J. W.

1977. A hook and line survey of the sharks found within five hundred meters of shore along Melbourne Beach, Brevard County, Florida. M.S. thesis, 304 p. Fla. Inst. Technol., Melbourne, FL.

Driggers, W. B., III, M. D. Campbell, K. M. Hannan, E. R. Hoffmayer, C. M. Jones, L. M. Jones, and A. G. Pollack.

2017. Influence of bait type on catch rates of predatory fish species on bottom longline gear in the northern Gulf of Mexico. Fish. Bull. 115:50-59. Crossref

Dulvy, N. K., S. L. Fowler, J. A. Musick, R. D. Cavanagh, P. M.

Kyne, L. R. Harrison, J. K. Carlson, L. N. K. Davidson, S. V. Fordham, M. P. Francis, et al.

2014. Extinction risk and conservation of the world's sharks and rays. eLife 3:e00590. Crossref

Ford, R. M.

2012. Diet and reproductive biology of the blacknose shark (Carcharhinus acronotus) from the southwestern Atlantic Ocean. M.S. thesis, 43 p. Univ. N. Fla., Jacksonville, FL.

Foster, D. G., S. P. Epperly, A. K. Shah, and J. W. Watson.

2012. Evaluation of hook and bait type on the catch rates in the western North Atlantic Ocean pelagic longline fishery. Bull. Mar. Sci. 88:529-545. Crossref
Hoffmayer, E. R., and G. R. Parsons.

2003. Food habits of three shark species from the Mississippi Sound in the northern Gulf of Mexico. Southeast. Nat. 2:271-280. Crossref

Kenney, R. D., R. E. Owen, and H. W. Winn.

1985. Shark distributions off the northeast United States from marine mammal surveys. Copeia 1985:220-223. Crossref

Litvinov, F. F.

2006. On the role of dense aggregations of males and juveniles in the functional structure of the range of the blue shark Prionace glauca. J. Ichthyol. 46:613-624. Crossref

Molina, J. M., and S. J. Cooke.

2012. Trends in shark bycatch research: current status and research needs. Rev. Fish Biol. Fish. 22:719-737. Crossref

Oliver, S., M. Braccini, S. J. Newman, and E. S. Harvey.

2015. Global patterns in the bycatch of sharks and rays. Mar. Policy 54:86-97. Crossref

Pitcher, T. J., A. E. Magurran, and I. J. Winfield.

1982. Fish in larger shoals find food faster. Behav. Ecol. Sociobiol. 10:149-151. Crossref

Stevens, J. D., and J. M. Lyle.

1989. Biology of three hammerhead shark (Eusphyra blochii, Sphyrna mokarran and S. lewini) from northern Australia. Aust. J. Mar. Freshw. Res. 40:129-146. Crossref

Szedlmayer, S. T., and J. D. Lee.

2004. Diet shifts of juvenile red snapper (Lutjanus campechanus) with changes in habitat and fish size. Fish. Bull. 102:366-375.

Torres-Rojas, Y. E., A. Hernández-Herrera, F. Galván-Magaña, and V. G. Alatorre-Ramírez.

2010. Stomach content analysis of juvenile, scalloped hammerhead shark Sphyrna lewini captured off the coast of Mazatlán, Mexico. Aquat. Ecol. 44:301-308. Crossref

Vaske, T., Jr., C. M. Vooren, and R. P Lessa.

2009. Feeding strategy of the night shark (Carcharhinus signatus) and scalloped hammerhead shark (Sphyrna lewini) near seamounts off northeastern Brazil. Braz. J. Oceanogr. 57:97-104. Crossref

Watson, J. W., S. P. Epperly, A. K. Shah, and D. G. Foster.

2005. Fishing methods to reduce sea turtle mortality associated with pelagic longlines. Can. J. Fish. Aquat. Sci. 62:965-981. Crossref

Wells, R. J. D., J. H. Cowan Jr., and B. Fry.

2008. Feeding ecology of red snapper Lutjanus campechanus in the northern Gulf of Mexico. Mar. Ecol. Prog. Ser. 361:213-225. Crossref

Yokota, K., M. Kiyota, and H. Okamura.

2009. Effect of bait species and color on sea turtle bycatch and fish catch in a pelagic longline fishery. Fish. Res. 97:53-58. Crossref 